\title{
Economic and Social Empowerment of Women in Egypt. Current and future status
}

\author{
Ahlam Ahmed Hassan \\ Department of Agricultural Economy, Agricultural and Biological Research Division, National \\ Research Centre, 33 El Buhouth St., 12622 Dokki, Giza, Egypt \\ Received: 10 Mar. 2020 / Accepted 20 May 2020 / Publication date: 15 June 2020
}

\begin{abstract}
Egyptian women have proved that they are able to take responsibility in various fields, led by increasing the economic empowerment of women through improving the participation of women in work and raising the proportion of projects directed to women, and importance of Women's Empowerment in societies is clear because Empowerment is one of the main procedural concerns when addressing human rights and development Women's Empowerment and achieving gender equality is essential for our society to ensure the sustainable development of the country. The research problem is the study of ways the Egyptian state seeks to increase the economic empowerment of women in Egypt, especially rural women. Thus, the study aimed to increase the economic and social empowerment of women, especially rural women, by owning and managing the means of production The most important results reached were that women constitute almost half of the society, and the average number of females reached about 41 million during the period (2007-2017), and the females percentage of the total population is about $49.20 \%$, which is high, therefore, it is large proportion cannot neglect its role and contribution to development.
\end{abstract}

Keywords: Economic Empowerment of Women, Social Empowerment of Women, Social Mobility, women's work, Political empowerment of women.

\section{Introduction}

The importance of women in society is evident from the fabric of society, Where society is composed of men and women equally, Coherent and homogeneous, Therefore, women have half of the society, also women have the same powers and rights as men in society, and Egyptian women have achieved many important gains in terms of access to decision-making positions, the new constitution included several articles, including articles 11,53 , which provided for equality between Women and men in all rights and work to ensure appropriate representation in the parliamentary councils, and ensure their right to assume the functions of senior management of the State, appointment to judicial bodies ,and the State's obligation to protect women from all forms of violence and eliminate all forms of discrimination, as Article 180 sets a quarter of seats for women councils The state's priorities for Egyptian women were micro-projects and support for female heads of household and poor families.

The number of women benefiting from microfinance in 2017 was about 1.33 million women with funding balances of 2.55 billion pounds. The state also provides early childhood services to allow the Egyptian mother to go out to work. Considering 2017 the year of the Egyptian woman as the culmination of her efforts and encouraging her to increase her role in the development of society, where the government and all state bodies, and the National Council for Women have been mandated, the time horizon for the implementation of that strategy will be 13 years.

\section{The Research Problem:}

Although the State seeks to increase the economic empowerment of women in general and rural women in particular, as evidenced by the acquisition of a large part of the 2030 development strategy, the current situation of women and rural women have many shortcomings and negative aspects, such as the low size of the female labor force For the total size of the labor force, and the high unemployment rate among females, especially rural women compared to males, although the proportion of educated females with middle and university qualifications in the appropriate age group for work (15-49) is high, but they are not employed, although this age group and educational level are Development tools in Egypt, in addition to the large proportion of females in the rural work in agricultural activity without

Corresponding Author: Ahlam Ahmed Hassan, Department of Agricultural Economy, Agricultural and Biological Research Division, National Research Centre, 33 El Buhouth St., 12622 Dokki, Giza, Egypt. E-mail: el_shahawy4@yahoo.com 
wages for the family as a family work, which led to a decline in their role in contributing to the family income, so they have no economic empowerment, and no opinion in making decisions in the family, Therefore, this reduces the role of women, especially rural women in development.

\section{Research Objective:}

The research aims to increase the economic and social empowerment of women in general and rural women in particular by owning and managing the means of production, and getting out of the Home work circle. And Work in the small and micro projects, and raise the percentage of projects directed to women, so that they can make economic decisions within the family and society, also reduce the rate of unemployment and poverty among females, especially in rural areas, by identifying the current status of women in terms of (education - work - economic activity (setting up and managing projects) - occupying leadership positions, and issues of violence against women during the period (2007-2017), also study the role of financial institutions in the development of women, and obstacles that Facing and assisting them in the economic and social empowerment, and creating a kind of social mobility for women.

\section{Data Source and Research Method:}

The study was based on published and unpublished data from the Central Agency for Public Mobilization and Statistics, The Small Enterprise Development Authority, Local Development Fund, and the Ministry of Social Solidarity during the period 2007-2017.

Also, it has been used the decisions of the National Council for Women, and researches related to the subject of the study, the study also used the method of descriptive and quantitative analysis with some economic indicators in the study of small enterprises and some statistical analysis tools, such as averages, percentages, number of projects, job opportunities, cost opportunity, the relative importance of women, and rural women in particular for their composition of the total population.

In addition to the labor force, unemployment and education during the period (2007-2017), and study the evolution of these variables over time by analyzing the time trend of the development of variables during the period (2007-2017), also, determine the target levels of economic, social, and political empowerment of women until 2030.

\section{Definition of some terms in the study:}

\section{Social Mobility:}

Is the transition of the individual upward in the class structure of society, including the development of its abilities, preparations and self-effort to obtain a high functional and social position within the community, and thus become a fertile area for the movement of its members (Mlak ElTahawy2016).

The social mobility of women can serve as a criterion or a measure of the state of society, because the more the societal view of women is civilized and developed, the more civilized and sophisticated society, and vice versa is true, with the observation that social development is not only linked to wealth and economic well-being, but intellectual richness, artistic and cultural creativity, In addition to the evolution of tradition and legacies with the march of time, and the evolution of life (Mona Desouky2015).

-Also it is defined as the social mobility of women is a change in the social status of women and their role, also their concepts and personal freedom and the rise or descent at the horizontal or vertical level in social construction, and that is through the work of women. (Salwa Khader 2018).

\section{The concept of women's work:}

Interest in the concept of women's work goes back to the beginning

The industrial revolution, when factory workers began to strike as a result of their exhaustion of long working hours and limited wages. Because of this, women have entered the field of work to cover the shortage of labor in factories for fear of stoppage and financial loss. The entry of women into the labor market was not a decision made by herself, but rather a societal reality that led them to take such a decision to save these factories from loss, without regard to the nature of women and their abilities, also the burden they bear (Iman Akour, 2016 ). 


\section{First: The Current Status of Women in Egypt:}

This section is concerned with identifying the current situation of women, and rural women in particular, as a human labor force in the Egyptian countryside, by examining their relative general characteristics, As Educational status, employment status, economic activity and the main occupations in rural areas. This has impacted the economic and social empowerment of women, and activated their role in development, as follows:

\section{Relative importance of women of population:}

Table (1) shows the number of population by gender during the period (2007-2017), and it is clear that women constitute about half of the society, where the average number of females about 41 million people during the period (2007-2017), and the average population about 82.06 million people. The proportion of females of the total population is about $49.20 \%$, which is high, thus the proportion of women of the total population is a significant proportion and its role and contribution to development.

Table 1: Population in Million by Gender (Males and Females) during the period (2007-2017)

\begin{tabular}{ccccc}
\hline Year & Male & Female & Total & Female\% of total population \\
\hline $\mathbf{2 0 0 7}$ & 37.29 & 35.65 & 72.94 & 48.88 \\
$\mathbf{2 0 0 8}$ & 38.54 & 36.54 & 75.08 & 48.67 \\
$\mathbf{2 0 0 9}$ & 38.9 & 37.19 & 76.09 & 48.88 \\
$\mathbf{2 0 1 0}$ & 39.79 & 38.54 & 78.33 & 49.20 \\
$\mathbf{2 0 1 1}$ & 40.71 & 38.9 & 79.61 & 48.86 \\
$\mathbf{2 0 1 2}$ & 41.7 & 39.89 & 81.59 & 48.89 \\
$\mathbf{2 0 1 3}$ & 42.73 & 42.94 & 85.67 & 50.12 \\
$\mathbf{2 0 1 4}$ & 43.79 & 43.99 & 87.78 & 50.11 \\
$\mathbf{2 0 1 5}$ & 44.88 & 43.7 & 88.58 & 49.33 \\
$\mathbf{2 0 1 6}$ & 45.94 & 44.14 & 90.08 & 49.00 \\
$\mathbf{2 0 1 7}$ & 46.96 & 45.16 & 92.12 & 49.02 \\
Average & 41.93 & 4.00 & 82.53 & 49.20 \\
\hline
\end{tabular}

Source: Central Agency for Public Mobilization and Statistics.

Classification of population to rural and urban population, where the table (2) shows that the rural population represents $57.27 \%$ of the total population. This percentage is higher than half, so the focus should be on rural areas in development, due to the high percentage of poor people in rural areas. Where the table (3) shows the percentage of poor people in the regions of Egypt in 2017, where the percentage of poor people in the North Egypt rural areas reached about 19.7\%, while it reached in the Upper Egypt rural areas about $56.7 \%$. The proportion of the poor people in the Republic about $27.8 \%$.

Table 2: Rural and urban population in million During the period (2007-2017)

\begin{tabular}{ccccc}
\hline Year & Urban & Rural & Total & \% Rural from the total \\
\hline $\mathbf{2 0 0 7}$ & 31.72 & 41.92 & 73.64 & 56.93 \\
$\mathbf{2 0 0 8}$ & 32.2 & 42.95 & 75.15 & 57.15 \\
$\mathbf{2 0 0 9}$ & 33.08 & 43.84 & 76.92 & 56.99 \\
$\mathbf{2 0 1 0}$ & 33.07 & 44.88 & 77.95 & 57.58 \\
$\mathbf{2 0 1 1}$ & 34.49 & 46.04 & 80.53 & 57.17 \\
$\mathbf{2 0 1 2}$ & 35.37 & 47.18 & 82.55 & 57.15 \\
$\mathbf{2 0 1 3}$ & 36.21 & 48.42 & 84.63 & 57.21 \\
$\mathbf{2 0 1 4}$ & 37.09 & 49.72 & 86.81 & 57.27 \\
$\mathbf{2 0 1 5}$ & 37.99 & 50.96 & 88.95 & 57.29 \\
$\mathbf{2 0 1 6}$ & 38.89 & 52.13 & 91.02 & 57.27 \\
$\mathbf{2 0 1 7}$ & 40.43 & 54.77 & 95.20 & 57.53 \\
Average & 35.50 & 47.53 & 83.03 & 57.24 \\
\hline
\end{tabular}

Source: Central Agency for Public Mobilization and Statistics.

Table 3: Percentage of the poor among the regions of Egypt in 2017

\begin{tabular}{lc}
\hline Region & Ratio \\
\hline Urban Governorates & 15.1 \\
North Egypt Urban & 9.7 \\
North Egypt Rural & 19.7 \\
Upper Egypt Urban & 27.4 \\
Upper Egypt Rural & 56.7 \\
Total Republic & 27.8 \\
\hline
\end{tabular}

Source: Central Agency for Public Mobilization and Statistics. 


\section{Educational status of women during the period (2007-2017):}

Table (4) indicates the relative importance of the recipients Preparatory, intermediate education and university graduates per thousand students by gender during the study period (2007-2017),also, the table shows the high percentage of females in the three stages, where they reached about $(50 \%$ $55 \%-54 \%$ ) of the total number of learners in the three stages respectively during the period (20072017), which shows the desire of females in education, development and qualify for the market Work, and improve their living and career.

Table 4: The relative importance of preparatory, intermediate education and university graduates per thousand students according to gender during the study period (2007-2017)

\begin{tabular}{|c|c|c|c|c|c|c|}
\hline \multirow{2}{*}{ Year } & \multicolumn{2}{|c|}{ Preparatory education } & \multicolumn{2}{|c|}{ Intermediate education } & \multicolumn{2}{|c|}{ Graduates of universities } \\
\hline & Male $\%$ & Female \% & Male \% & Female \% & Male $\%$ & Female \% \\
\hline 2007 & 49.82 & 50.18 & 46.69 & 53.31 & 47.81 & 52.19 \\
\hline 2008 & 50.45 & 49.55 & 46.85 & 53.15 & 47.41 & 52.59 \\
\hline 2009 & 49.24 & 50.76 & 46.45 & 53.55 & 44.83 & 55.17 \\
\hline 2010 & 49.56 & 50.44 & 44.49 & 55.51 & 45.5 & 54.5 \\
\hline 2011 & 50.2 & 49.8 & 34.25 & 65.75 & 45.86 & 54.14 \\
\hline 2012 & 50.2 & 49.8 & 44.49 & 55.51 & 46.17 & 53.83 \\
\hline 2013 & 50.02 & 49.98 & 45.72 & 54.28 & 46.74 & 53.26 \\
\hline 2014 & 50.25 & 49.75 & 45.43 & 54.57 & 45.75 & 54.25 \\
\hline 2015 & 49.67 & 50.33 & 45.38 & 54.62 & 46.52 & 53.48 \\
\hline 2016 & 50.3 & 50.4 & 45.85 & 54.15 & 43.6 & 56.4 \\
\hline 2017 & 50.48 & 49.52 & 46.02 & 54.21 & 43.83 & 56.17 \\
\hline Average & 50.04 & 50.13 & 44.82 & 55.2 & 45.77 & 54.23 \\
\hline
\end{tabular}

Source: Central Agency for Public Mobilization and Statistics.

Studying the general time trend of the development of the women education with respect to Preparatory, intermediate education, university graduates, where the results of the analysis proved the significance of the model for the development of women with a preparatory education at the level of $5 \%$, and that this development occurs at an increasing about 0.764 , and that the value of $\mathrm{R}^{12}$ (The adjusted determination coefficient ) is equal $60 \%$, means that $60 \%$ of the developments occur to the women that get the preparatory education are due to the element of time. Also for those with intermediate education, the model was also significant at the level of $1 \%$, and that this development is occurring at an increasing about 0.911 , and that the value of $\mathrm{R}^{\prime 2}$ equals $83 \%$ means that $83 \%$ of the developments that happen to women with intermediate education are due to the element of time. Also, the significance of the model was evident for the development of university degree holders at the level of $1 \%$, and that this development occurs at an increasing rate of 0.789 , and the value of $\mathrm{R}^{\prime 2}$ is equal to $62 \%$ means that $62 \%$ of the developments that happen to hold a university degree due to the element of time as shown in Table (5).

Table 5: Results of the general time trend equations analysis of the Preparatory education for females, Intermediate education for females, and University qualification for females, during the period (2007-2017).

\begin{tabular}{|c|c|c|c|c|c|}
\hline $\begin{array}{c}\text { Equation } \\
\text { number }\end{array}$ & Statement & Equation & Average & $\mathbf{R}^{\prime 2}$ & $\mathbf{F}$ \\
\hline 1 & Preparatory education for females & $\begin{array}{c}\mathrm{Y}=481.85+0.764 \mathrm{X} \\
(12.79)^{* *}(3.55)^{*}\end{array}$ & 741.9 & $60 \%$ & $12.61^{* *}$ \\
\hline 2 & Intermediate education for females & $\begin{aligned} Y= & 167+0.911 X \\
& (6.63)^{* *}(32.44)^{* *}\end{aligned}$ & 263 & $83 \%$ & $43.89^{* *}$ \\
\hline 3 & University qualification for females & $\begin{aligned} Y= & 161.13+0.789 \mathrm{X} \\
& (3.86)^{* *}(26.26)^{* *}\end{aligned}$ & 182.06 & $62 \%$ & $14.87^{* *}$ \\
\hline
\end{tabular}

Source: Compiled and calculated from table data $4,(*)$ Significant at $5 \%,(* *)$ Significant at $1 \%$

Status of Women's Work in Egypt (2007-2017):

Women have a considerable capacity and energy, both at work and in decision-making, but it untapped energy.

Table (6) indicates the labor force, the employed, the unemployed, and the unemployment rate for males and females in Egypt during the period (2007 - 2017), where the average labor force during 
the study period was about 269 thousand workers, employment of the average age (15-64 year), which is the appropriate age for work. The proportion of females in the total labor force was about $23.36 \%$, the proportion of the total number of workers $20.35 \%$, and the proportion of the total number of unemployed about $46.80 \%$, a high percentage of nearly half of the total number of unemployed, which amounted to about 30.6 thousand workers, and the unemployment rate among females About $72.44 \%$ of the unemployment rate in the Republic, which amounted to about $11.36 \%$. The unemployment rate among males was $7.8 \%$. Unemployment rate among females is high despite the high rate of university education among females, although the desire and ability to work, which indicates that women's energy is wasted and underutilized efficiently.

Table 6: Labor Force, Employees, Unemployed and Unemployment Rate for Males and Females in Egypt during the Period (2007-2017)

\begin{tabular}{|c|c|c|c|c|c|c|}
\hline \multirow{2}{*}{ Year } & \multicolumn{3}{|c|}{ Labor Force } & \multicolumn{3}{|c|}{ Employees } \\
\hline & Males & Females & Total & Males & Females & Total \\
\hline 2007 & 181.67 & 56.92 & 238.59 & 170.89 & 46.34 & 217.23 \\
\hline 2008 & 191.2 & 55.32 & 246.52 & 180.42 & 44.66 & 225.08 \\
\hline 2009 & 194.1 & 59.43 & 253.53 & 183.97 & 45.78 & 229.75 \\
\hline 2010 & 201.4 & 60.4 & 261.8 & 191.53 & 46.76 & 238.29 \\
\hline 2011 & 205.41 & 59.88 & 265.29 & 187.19 & 46.27 & 233.46 \\
\hline 2012 & 208.7 & 61.45 & 270.15 & 189.32 & 46.64 & 235.96 \\
\hline 2013 & 211.66 & 64.56 & 276.22 & 190.82 & 48.91 & 239.73 \\
\hline 2014 & 213.15 & 66.29 & 279.44 & 192.64 & 50.35 & 242.99 \\
\hline 2015 & 217.26 & 67.05 & 284.31 & 196.94 & 50.85 & 247.79 \\
\hline 2016 & 219.4 & 69.99 & 289.39 & 199.86 & 53.45 & 253.31 \\
\hline 2017 & 224.73 & 70.2 & 294.93 & 206.3 & 53.86 & 260.16 \\
\hline Average & 206.24 & 62.86 & 269.11 & 189.99 & 48.53 & 238.52 \\
\hline $\begin{array}{l}\% \text { Females } \\
\text { Of the total }\end{array}$ & \multicolumn{3}{|c|}{23.36} & \multicolumn{3}{|c|}{20.35} \\
\hline
\end{tabular}

Table 6: Continued:

\begin{tabular}{|c|c|c|c|c|c|c|}
\hline \multirow{2}{*}{ Year } & \multicolumn{3}{|c|}{ Unemployed } & \multicolumn{3}{|c|}{ Unemployment Rate } \\
\hline & Males & Females & Total & Males & Females & Total \\
\hline 2007 & 10.77 & 10.58 & 21.4 & 5.9 & 18.6 & 8.95 \\
\hline 2008 & 10.78 & 10.6 & 21.4 & 5.6 & 19.3 & 8.67 \\
\hline 2009 & 10.13 & 13.65 & 23.8 & 5.2 & 23 & 9.38 \\
\hline 2010 & 9.87 & 13.64 & 23.5 & 4.9 & 22.6 & 8.98 \\
\hline 2011 & 18.22 & 13.61 & 31.8 & 8.9 & 22.7 & 12.00 \\
\hline 2012 & 19.42 & 14.83 & 34.3 & 9.3 & 24.1 & 12.68 \\
\hline 2013 & 20.84 & 15.65 & 36.5 & 9.8 & 24.2 & 13.21 \\
\hline 2014 & 20.52 & 15.94 & 36.5 & 9.6 & 24 & 13.05 \\
\hline 2015 & 20.32 & 16.19 & 36.5 & 9.4 & 24.2 & 12.84 \\
\hline 2016 & 19.48 & 16.55 & 36 & 8.9 & 23.6 & 12.45 \\
\hline 2017 & 18.53 & 16.15 & 34.7 & 8.2 & 23.9 & 11.76 \\
\hline Average & 16.26 & 14.31 & 30.6 & 7.79 & 22.75 & 11.36 \\
\hline $\begin{array}{l}\% \text { Females } \\
\text { Of the total }\end{array}$ & & 46.80 & & & 72.44 & \\
\hline
\end{tabular}

Source: Central Agency for Public Mobilization and Statistics.

\section{Studying the general trend of the development of the labor force, the employed, the unemployed and the unemployment rate for women.}

Where the equations in Table (7) show the significance of the evolution in the workforce of women where the significance at the level of $1 \%$, and that this development occurs at an increasing rate of 0.976 , and the value of $\mathrm{R}^{\prime 2}$ is equal to $95 \%$ means that $95 \%$ of the developments in the workforce due to the element time, Also, the development of the number of workers for women, where the significance proved at the level of $1 \%$, and that this development occurs at an increasing about of 0.930 , and the value of $\mathrm{R}^{\prime 2}$ is equal to $86 \%$ means that $86 \%$ of the developments that occur in the number of workers for women due to the time element. Also the unemployed proved to be significant at the level of $1 \%$, and that this development is happening at an increasing rate of 0.930 and the value of $\mathrm{R}^{\prime 2}$ is 
$86 \%$ means that $86 \%$ of the developments that occur in the number of unemployed for women due to the element of time. Also, the unemployment rate for women proved to be significant for the increase in women's unemployment rate at $5 \%$. This development is taking place at an increasing rate of 0.789 , and the value of $\mathrm{R}^{\prime 2}$ equals $62 \%$ means that $62 \%$ of the developments in the unemployment rate for women are due to the time element. The model summarizes that all variables in the model increase at rate is increasing and continuous over time. As shown in Table (7).

Table 7: Results of the general time trend equations analysis of the labor force, the employed, the unemployed and the unemployment rate for women during the period (2007-2017)

\begin{tabular}{clcccc}
\hline $\begin{array}{c}\text { Equation } \\
\text { number }\end{array}$ & Statement & Equation & Average & $\mathbf{R}^{\prime 2}$ & $\mathbf{F}$ \\
\hline $\mathbf{1}$ & Workforce of women & $\begin{array}{c}\mathrm{Y}=53.89+0.976 \mathrm{X} \\
(72.06)^{* *}(13.55)^{* *}\end{array}$ & 62.86 & $95 \%$ & $183.60^{* *}$ \\
$\mathbf{2}$ & Employed women & $\begin{array}{c}\mathrm{Y}=43.2+0.930 \mathrm{X} \\
(54.21)^{* *}(7.57)^{* *}\end{array}$ & 48.53 & $86 \%$ & $57.25^{* *}$ \\
$\mathbf{3}$ & Unemployed women & $\begin{array}{c}\mathrm{Y}=10.71+0.929 \mathrm{X} \\
(19.93)^{* *}(7.5)^{* *}\end{array}$ & 14.31 & $86 \%$ & $57.14^{* *}$ \\
$\mathbf{4}$ & Women's unemployment rate $\begin{array}{c}\mathrm{Y}=19.93+0.789 \mathrm{X} \\
(24.16)^{* *}(3.86)^{*}\end{array}$ & 22.75 & $62 \%$ & $14.87^{*}$ \\
\hline
\end{tabular}

The study of the current situation of employment in the average age of (15-64) males and females according to the economic activity during the period (2013-2017), where Table (8) indicates that the highest sectors in terms of women's participation in the health, social and religious services sector at 29 thousand workers, of which women accounted for about $35.5 \%$, followed by the agriculture and water resources sector in the second place, and the average number of workers about 21.86 thousand workers, the proportion of women participation of about $24.8 \%$, and then the financial sector and economy in the third place, and the average employees about 63.4 Thousands of women participated in the workforce, of which about $23 \%$. It was followed by other sectors (supply and internal trade, culture and media, tourism and aviation, electricity, industry, petroleum, defense and security, transport and communications, housing and construction) respectively, where the participation rate of women (18\% $-17.5 \%-15.7 \%-12.1 \%-10.3 \%-9.5 \%-8 \%-6.5 \%)$ respectively.

Studying the distribution of workers in government sector institutions, according to the economic sector and the functional financial degree, and the relative importance of females in 2017, where table( 9) shows that the sectors (health and social services, housing and construction, and electricity) are the highest sectors in terms of women's participation in the excellent financial degree it reached about $(42.9 \%-32.8 \%-13.8 \%)$ respectively, Then other sectors follow, With regard to the high financial degree, the highest participation rate in the health and social services sector was achieved at a rate of about $40.9 \%$. Also, the general manager financial degree is reached about $40.7 \%$. Then, the other grades follow, while the health and social services sector occupies the highest participation rate for women in the first to sixth financial levels, also in private cadres and contracts with a participation rate of about $(35.8 \%$ - 39.4- $33.2 \% 31.3-23.6 \%$ - $23.9 \%$ - $44.8 \%-34.5 \%)$, respectively.

\section{The status of women's economic activity in Egypt during the period (2007-2017):}

The study of the economic activity of women Through studying the role of the most important financing institutions in financing projects and providing job opportunities for women during the period (2007-2017), where Table (10) shows the number of projects ,the value of financing, employment opportunities, the proportion of the number of women's projects and financing of the most important financing institutions in Egypt During the study period, the data show that the Ministry of Social Solidarity is the highest for the financing of women's projects, also the number of women projects where the proportion of funding for women was about $55.4 \%$, the proportion of women projects amounted to about $70 \%$, and then the local development fund in terms of the number of women projects where it reached about $59.59 \%$, while the percentage of women financing was about $5 \%$ compared to other institutions. Then the institution of the small enterprise development, where the proportion of the number of women projects about $49 \%$, and the proportion of women financing about $15 \%$, While the provision of employment opportunities for the total females and males is the highest in the small enterprise development, which was provided about 266.9 thousand jobs during the average period 
(2007-2017), followed by the Ministry of Social Solidarity, where the average available job opportunities about 233 thousand jobs, Then the local development fund ranked last with an average of 6.5 thousand job opportunities.

Table 8: Employment in Average Age15-64) Males and Females by Economic Activity during the Period (2013-

\begin{tabular}{|c|c|c|c|c|c|c|c|c|c|c|c|}
\hline \multirow[t]{2}{*}{ Year } & \multicolumn{3}{|c|}{2013} & \multicolumn{3}{|c|}{2014} & \multicolumn{3}{|c|}{2015} & \multirow[b]{2}{*}{ 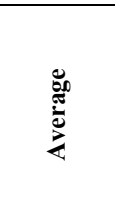 } & \multirow[b]{2}{*}{ 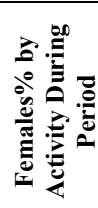 } \\
\hline & $\frac{\tilde{e}}{\tilde{J}}$ & 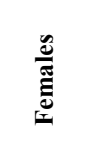 & 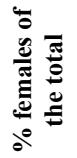 & $\frac{\tilde{\Xi}}{\Sigma}$ & 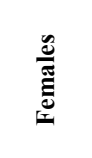 & 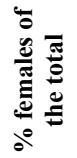 & $\frac{\tilde{g}}{\tilde{J}}$ & 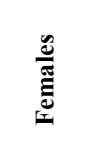 & 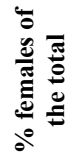 & & \\
\hline $\begin{array}{l}\text { Agriculture, Public } \\
\text { Works and Water } \\
\text { Resources Sector }\end{array}$ & 18725 & 5750 & 23.49 & 17061 & 5434 & 24.16 & 16934 & 5545 & 24.67 & 21858.2 & 24.8 \\
\hline $\begin{array}{l}\text { Industry, } \\
\text { Petroleum and } \\
\text { Mineral Resources } \\
\text { Sector }\end{array}$ & 199613 & 22133 & 9.98 & 197555 & 22296 & 10.14 & 195043 & 22319 & 10.27 & 215584.2 & 10.3 \\
\hline Electricity Sector & 123721 & 17111 & 12.15 & 126671 & 17100 & 11.89 & 118273 & 16350 & 12.15 & 136754.2 & 12.1 \\
\hline $\begin{array}{l}\text { Transport Sector } \\
\text { Supply and }\end{array}$ & 48196 & 4219 & 8.05 & 48287 & 4321 & 8.21 & 48741 & 4218 & 7.96 & 52203 & 8.0 \\
\hline $\begin{array}{l}\text { internal trade } \\
\text { sector }\end{array}$ & 29326 & 6373 & 17.85 & 28968 & 6308 & 17.88 & 28420 & 6243 & 18.01 & 34636 & 18.0 \\
\hline $\begin{array}{l}\text { Finance and } \\
\text { Economy }\end{array}$ & 49173 & 14031 & 22.20 & 49203 & 14561 & 22.84 & 49424 & 14258 & 22.39 & 63396.2 & 23.0 \\
\hline $\begin{array}{l}\text { Housing and } \\
\text { Construction } \\
\text { Sector }\end{array}$ & 205004 & 17063 & 7.68 & 214566 & 15236 & 6.63 & 202993 & 14887 & 6.83 & 221206 & 6.9 \\
\hline $\begin{array}{l}\text { Health, social and } \\
\text { religious services } \\
\text { sector }\end{array}$ & 18318 & 10388 & 36.19 & 19159 & 10562 & 35.54 & 19383 & 10582 & 35.31 & 29029 & 35.5 \\
\hline $\begin{array}{l}\text { Culture and media } \\
\text { sector }\end{array}$ & 1965 & 424 & 17.75 & 2189 & 464 & 17.49 & 2145 & 458 & 17.60 & 2340.4 & 17.4 \\
\hline $\begin{array}{l}\text { Tourism and } \\
\text { Aviation Sector }\end{array}$ & 42962 & 8178 & 15.99 & 42460 & 8041 & 15.92 & 42150 & 8039 & 16.02 & 49666 & 15.7 \\
\hline $\begin{array}{l}\text { Defense and } \\
\text { Security Sector }\end{array}$ & 25538 & 2704 & 9.57 & 25781 & 2682 & 9.42 & 24983 & 2720 & 9.82 & 27114.2 & 9.5 \\
\hline
\end{tabular}

Source: Central Agency for Public Mobilization and Statistics.

Table 8: Continued

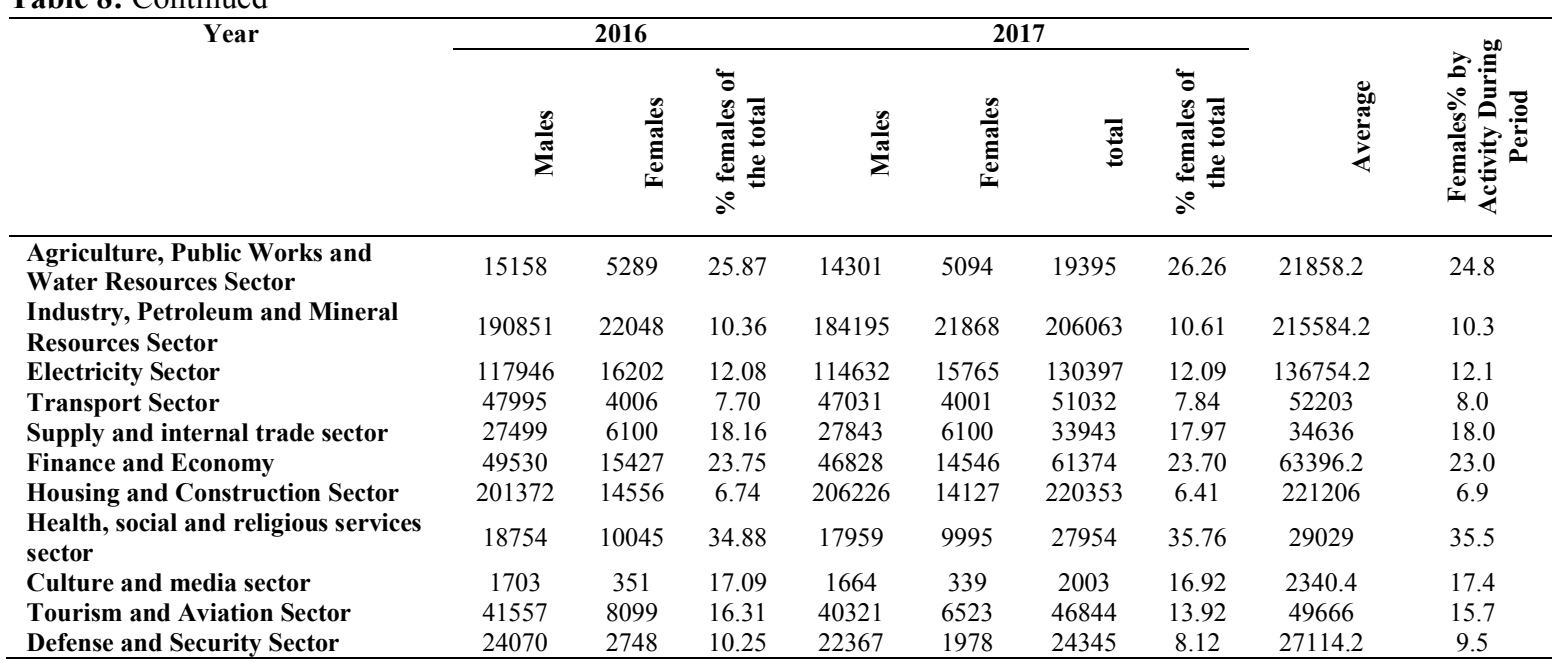


Table 9: Distribution of Employees in the Public Business Sector and the Public Sector by Economic Sector and Functional financial degree and relative importance of females in 2017

\begin{tabular}{|c|c|c|c|c|c|c|c|}
\hline $\begin{array}{l}\text { Economic Sector / Financial } \\
\text { Grade Type }\end{array}$ & Type & Excellent & High & $\begin{array}{l}\text { General } \\
\text { Manager }\end{array}$ & Senior & First & Second \\
\hline $\begin{array}{l}\text { Agriculture, public works } \\
\text { and water resources }\end{array}$ & $\% \mathrm{FT}$ & 0 & 4 & 14.61 & 26.1 & 31.5 & 34.8 \\
\hline $\begin{array}{l}\text { Industry, Petroleum and } \\
\text { Mineral Resources }\end{array}$ & $\% \mathrm{FT}$ & 8.4 & 11.9 & 12.5 & 9.6 & 7.1 & 7.7 \\
\hline Electricity & $\% \mathrm{FT}$ & 13.92 & 15.6 & 15.73 & 20.8 & 15.2 & 12.7 \\
\hline $\begin{array}{l}\text { Transport and } \\
\text { communications }\end{array}$ & $\% \mathrm{FT}$ & 0 & 16.3 & 23.1 & 25.75 & 13.3 & 9.56 \\
\hline Supply and internal trade & $\% \mathrm{FT}$ & 0 & 10.7 & 19.9 & 23.9 & 25 & 25.3 \\
\hline Finance and Economy & $\% \mathrm{FT}$ & 0 & 15.7 & 20.6 & 39.6 & 21.7 & 28.5 \\
\hline Housing and Construction & $\% \mathrm{FT}$ & 32.8 & 13.1 & 20.3 & 25.6 & 13.2 & 12 \\
\hline Housing and Construction & $\% \mathrm{FT}$ & 42.9 & 40.9 & 40.7 & 37.2 & 35.8 & 39.4 \\
\hline Culture and Media & $\% \mathrm{FT}$ & 0 & 0 & 21.9 & 46.7 & 12.6 & 14.5 \\
\hline
\end{tabular}

Table 9: Continued:

\begin{tabular}{|c|c|c|c|c|c|c|c|c|c|}
\hline $\begin{array}{c}\text { Economic Sector / } \\
\text { Financial Grade } \\
\text { Type }\end{array}$ & Type & Third & Fourth & Fifth & Sixth & $\begin{array}{c}\text { Comprehensive } \\
\text { Rewards }\end{array}$ & Contracts & $\begin{array}{c}\text { Special } \\
\text { Cadre }\end{array}$ & Total \\
\hline $\begin{array}{l}\text { Agriculture, } \\
\text { public works and } \\
\text { water resources }\end{array}$ & $\% \mathrm{FT}$ & 28 & 28.8 & 23.6 & 6.7 & 2.4 & 3.7 & 0 & 26.3 \\
\hline $\begin{array}{l}\text { Industry, } \\
\text { Petroleum and } \\
\text { Mineral } \\
\text { Resources }\end{array}$ & $\% \mathrm{FT}$ & 7.5 & 8.2 & 22.1 & 19.6 & 8.9 & 9.4 & 12.7 & 10.6 \\
\hline Electricity & $\% \mathrm{FT}$ & 10.3 & 5.5 & 1.2 & 2.5 & 13 & 5.1 & 0 & 12.1 \\
\hline $\begin{array}{l}\text { Transport and } \\
\text { communications }\end{array}$ & $\% \mathrm{FT}$ & 7.96 & 1.92 & 0.22 & 0.13 & 4.72 & 5.24 & 0 & 7.84 \\
\hline $\begin{array}{l}\text { Supply and } \\
\text { internal trade }\end{array}$ & $\% \mathrm{FT}$ & 20.7 & 10.4 & 3 & 3.5 & 16.7 & 10.7 & 0 & 18 \\
\hline $\begin{array}{l}\text { Finance and } \\
\text { Economy }\end{array}$ & $\% \mathrm{FT}$ & 27.4 & 10.1 & 4 & 1.6 & 38.4 & 22.3 & 25 & 23.7 \\
\hline $\begin{array}{l}\text { Housing and } \\
\text { Construction }\end{array}$ & $\% \mathrm{FT}$ & 8.6 & 2.2 & 0.3 & 1.4 & 2.7 & 3.2 & 2.8 & 6.4 \\
\hline $\begin{array}{l}\text { Housing and } \\
\text { Construction }\end{array}$ & $\% \mathrm{FT}$ & 33.2 & 31.3 & 23.6 & 23.9 & 0 & 34.5 & 44.8 & 35.8 \\
\hline $\begin{array}{l}\text { Culture and } \\
\text { Media }\end{array}$ & $\% \mathrm{FT}$ & 20.7 & 7.9 & 2.7 & 6.7 & 0 & 0 & 0 & 16.9 \\
\hline
\end{tabular}

Source: Central Agency for Public Mobilization and Statistics. \% FT: female from the total

Table 10: Number of Projects, Value of Funding, Job Opportunities and Percentage of Women Projects and their Financing of the Most Important Financial Institutions in Egypt During the Period (207-2017)

\begin{tabular}{|c|c|c|c|c|c|c|c|}
\hline \multirow[b]{2}{*}{ Year } & \multicolumn{7}{|c|}{ Ministry of Social Solidarity } \\
\hline & $\begin{array}{c}\text { Number of } \\
\text { projects } \\
\text { per } \\
\text { thousand }\end{array}$ & $\begin{array}{l}\text { Funding } \\
\text { value in } \\
\text { million }\end{array}$ & $\begin{array}{c}\text { Job } \\
\text { opportunities } \\
\text { for women in } \\
\text { thousands }\end{array}$ & $\begin{array}{l}\text { Number of } \\
\text { women } \\
\text { projects in } \\
\text { thousands }\end{array}$ & $\begin{array}{c}\text { Project } \\
\text { value of } \\
\text { women } \\
\text { financing in } \\
\text { million }\end{array}$ & $\begin{array}{c}\% \\
\text { Women } \\
\text { financing }\end{array}$ & $\begin{array}{c}\% \\
\text { Number } \\
\text { of women } \\
\text { projects }\end{array}$ \\
\hline 2007 & 132.08 & 1079 & 198.11 & 90 & 900 & 83.41 & 68.14 \\
\hline 2008 & 142.16 & 1345 & 170.58 & 102 & 747 & 55.54 & 71.75 \\
\hline 2009 & 136.14 & 1034 & 190.59 & 98 & 542 & 52.42 & 71.98 \\
\hline 2010 & 165.12 & 1115 & 231.16 & 120 & 650 & 58.3 & 72.67 \\
\hline 2011 & 144.94 & 1744 & 202.91 & 105 & 865 & 49.6 & 72.44 \\
\hline 2012 & 165.97 & 2150 & 232.36 & 110 & 990 & 46.05 & 66.27 \\
\hline 2013 & 186.81 & 2374 & 261.52 & 122 & 1050 & 44.23 & 65.3 \\
\hline 2014 & 178.32 & 2966.9 & 258.4 & 112 & 2034 & 68.56 & 62.8 \\
\hline 2015 & 207.62 & 4488.3 & 159.81 & 170 & 2000 & 44.56 & 81.88 \\
\hline 2016 & 205.06 & 3990 & 268.94 & 156 & 1980 & 49.62 & 76.07 \\
\hline 2017 & 220.56 & 6435 & 289.04 & 155 & 3678 & 57.16 & 70.27 \\
\hline Average & 171.34 & 2611.2 & 223.95 & 121.82 & 1403.27 & 55.4 & 70.88 \\
\hline
\end{tabular}


Table 10: Continued:

\begin{tabular}{|c|c|c|c|c|c|c|c|}
\hline \multirow[b]{2}{*}{ Year } & \multicolumn{7}{|c|}{ Small Enterprise Development Authority } \\
\hline & $\begin{array}{l}\text { Number of } \\
\text { projects per } \\
\text { thousand }\end{array}$ & $\begin{array}{l}\text { Funding } \\
\text { value in } \\
\text { million }\end{array}$ & $\begin{array}{c}\text { Job } \\
\text { opportunities } \\
\text { for women in } \\
\text { thousands }\end{array}$ & $\begin{array}{l}\text { Number } \\
\text { of women } \\
\text { projects } \\
\text { in } \\
\text { thousands }\end{array}$ & $\begin{array}{c}\text { Project } \\
\text { value of } \\
\text { women } \\
\text { financing in } \\
\text { million }\end{array}$ & $\begin{array}{c}\% \\
\text { Women } \\
\text { financing }\end{array}$ & $\begin{array}{c}\% \\
\text { Number } \\
\text { of women } \\
\text { projects }\end{array}$ \\
\hline 2007 & 178.94 & 1027 & 275.61 & 110.7 & 174.89 & 17.02 & 61.88 \\
\hline 2008 & 202.81 & 1290 & 316.37 & 115 & 216.88 & 16.81 & 56.73 \\
\hline 2009 & 203.71 & 1034 & 284.06 & 119.4 & 253.95 & 24.55 & 58.59 \\
\hline 2010 & 165.35 & 1117 & 228.72 & 85.29 & 217.65 & 19.49 & 51.58 \\
\hline 2011 & 145.14 & 1760 & 218.13 & 66.4 & 199.27 & 11.32 & 45.75 \\
\hline 2012 & 174 & 2175 & 213.72 & 74.29 & 169.53 & 7.79 & 42.69 \\
\hline 2013 & 186.82 & 2376 & 229.65 & 77.26 & 314.83 & 13.25 & 41.35 \\
\hline 2014 & 178.43 & 3030 & 218.32 & 75.66 & 348.19 & 11.49 & 42.4 \\
\hline 2015 & 189.06 & 4488 & 299.43 & 84.18 & 515.01 & 11.48 & 44.53 \\
\hline 2016 & 188.13 & 3764 & 265.17 & 91.32 & 590.97 & 15.7 & 48.54 \\
\hline 2017 & 232.69 & 5065 & 386.53 & 119.5 & 925.99 & 18.28 & 51.35 \\
\hline Average & 185.91 & 2466 & 266.88 & 92.64 & 357.2 & 15.2 & 49.58 \\
\hline
\end{tabular}

Table 10: Continued:

\begin{tabular}{|c|c|c|c|c|c|c|c|}
\hline \multirow[b]{2}{*}{ Year } & \multicolumn{7}{|c|}{ Local Development Fund } \\
\hline & $\begin{array}{c}\text { Number of } \\
\text { projects per } \\
\text { thousand }\end{array}$ & $\begin{array}{l}\text { Funding } \\
\text { value in } \\
\text { million }\end{array}$ & $\begin{array}{c}\text { Job } \\
\text { opportunities } \\
\text { for women in } \\
\text { thousands }\end{array}$ & $\begin{array}{c}\text { Number } \\
\text { of women } \\
\text { projects } \\
\text { in } \\
\text { thousands }\end{array}$ & $\begin{array}{c}\text { Project } \\
\text { value of } \\
\text { women } \\
\text { financing } \\
\text { in million }\end{array}$ & $\begin{array}{c}\% \\
\text { Women } \\
\text { financing }\end{array}$ & $\begin{array}{c}\% \\
\text { Number } \\
\text { of women } \\
\text { projects }\end{array}$ \\
\hline 2007 & 9.387 & 31.21 & 9.38 & 5.12 & 16.48 & 5.28 & 54.54 \\
\hline 2008 & 7.35 & 24.17 & 7.35 & 4.31 & 13.33 & 5.52 & 58.64 \\
\hline 2009 & 11.381 & 40.8 & 11.3 & 6.04 & 20.54 & 5.04 & 53.07 \\
\hline 2010 & 7.2 & 26.17 & 7.2 & 4.08 & 13.01 & 4.97 & 56.67 \\
\hline 2011 & 9.076 & 31.63 & 9.07 & 5.1 & 17.03 & 5.39 & 56.19 \\
\hline 2012 & 7.101 & 25.57 & 7.1 & 4.12 & 14.02 & 5.48 & 58.02 \\
\hline 2013 & 5.166 & 18.18 & 5.16 & 3.22 & 11.1 & 6.11 & 62.33 \\
\hline 2014 & 6.626 & 24.78 & 6.62 & 4.05 & 14.75 & 5.95 & 61.12 \\
\hline 2015 & 3.821 & 19.71 & 3.82 & 2.24 & 11.23 & 5.7 & 58.62 \\
\hline 2016 & 2.923 & 14.02 & 2.92 & 1.96 & 8.981 & 6.4 & 67.05 \\
\hline 2017 & 1.704 & 6.95 & 1.7 & 1.18 & 4.642 & 6.67 & 69.25 \\
\hline Average & 6.52 & 23.9 & 6.5 & 3.77 & 13.2 & 5.68 & 59.59 \\
\hline
\end{tabular}

Source: Central Agency for Public Mobilization and Statistics

Studying the development of the number of women's projects and their financing, Through the most important financing institutions during the study period (2007-2017), by using an analysis of the general time trend of the evolution of the number of women's projects, where the equations in Table (11) show the significance of the development, and increase of the number of women projects established through the Ministry of Social Solidarity at the level $1 \%$, and that this development is occurring at an increasing amount of 0.859 , and an average of 121.82 thousand projects, the value of $\mathrm{R}^{\prime 2}$ equals $73 \%$, meaning that $73 \%$ of the developments that occur in the number of women's projects through the Ministry of Social Solidarity are due to the element of time. While the significance of the development in the number of women's projects has not been proven through the Small Enterprise Development Authority and that it has changed by a decreasing amount of 0.251 , and an average of 92.6 thousand projects, that $62 \%$ of the changes in the number of women projects established through the Small Enterprise Development Authority are due to the element of time. With regard to the number of women's projects through the Local Development Fund, the model's significance has been established at the level of $1 \%$, and that this development occurs at a decreasing amount of 0.863 , and an average of 3.77 thousand projects , that the value of $\mathrm{R}^{/ 2}$ equals $74 \%$, meaning that $74 \%$ of the developments that occur in the number of women's projects through the local development fund are due to the time element. 
Table 11: Results of the analysis of the general time trend equations for the number of women projects in the most important financial institutions during the period (2007-2017)

\begin{tabular}{cllcccc}
\hline $\begin{array}{c}\text { Equation } \\
\text { number }\end{array}$ & Statement & Equation & Average & $\mathbf{R}^{\prime 2}$ & F \\
\hline $\mathbf{1}$ & $\begin{array}{l}\text { Ministry of Social } \\
\text { Thousands project }\end{array}$ & Solidarity per & $\begin{array}{c}\mathrm{Y}=80.47+0.859 \mathrm{X} \\
(8.69) * *(5.02)^{* *}\end{array}$ & 121.82 & $73 \%$ & $52.24^{* *}$ \\
$\mathbf{2}$ & $\begin{array}{l}\text { Small Enterprise } \\
\text { Authority per projects }\end{array}$ & $\begin{array}{c}\mathrm{Y}=101.65-0.251 \mathrm{X} \\
(7.76) * *(-0.777)\end{array}$ & 92.64 & $63 \%$ & 0.6 \\
$\mathbf{3}$ & Local Development & $\begin{array}{c}\mathrm{Y}=6.08+0.863 \mathrm{X} \\
(11.94) * *(-5.14) * *\end{array}$ & 3.77 & $74 \%$ & $26.38^{* *}$ \\
\hline
\end{tabular}

Source: Compiled and calculated from table data (10), $\left({ }^{*}\right)$ Significant at 5\%, $\left({ }^{* *}\right)$ Significant at 1\%

With regard to financing women's projects through those institutions, table (12) shows the results of analyzing the general time trend equations for the value of financing women's projects through the most important financing institutions, the significance of the value model for women's projects financing through the Ministry of Social Solidarity is proven at the level of $1 \%$, and this development takes place With an increasing amount of 0.839 , and an average of 1.4 billion pounds, and that the value of $\mathrm{R}^{/ 2}$ equal $67 \%$, which means that $67 \%$ of the developments that occur in the financing of women's projects through the Ministry of Social Solidarity are due to the element of time. Level 5\% This development is taking place at an increasing amount of 0.896 , and an average of 357.2 million pounds, and the value of $\mathrm{R}^{\prime 2}$ equal $65 \%$, meaning that $65 \%$ of the developments that occur in financing women's projects through the Small Enterprise Development Authority are due to the element of time, While the significance of funding women's projects through the Local Development Fund has not been proved, and women's funding changes by a decreasing amount of 0.757 . And an average of 13.2 million pounds.

\section{Second: The targeted situation:}

Studying the targeted situation through analyzing the women's empowerment strategy 2030, which is derived from the sustainable development agenda, which is the working document for the coming years to activate the plans, programs and projects included therein, and the time period for implementing this strategy will extend for 13 years.

Table 12: Results of thegeneral time trend analysis equations of the value of financing women's projects in the most important financial institutions during the study period (2007-2017).

\begin{tabular}{cllccc}
\hline $\begin{array}{c}\text { Equation } \\
\text { number }\end{array}$ & statement & Equation & Average & $\mathbf{R}^{\prime 2}$ & F \\
\hline \multirow{2}{*}{$\begin{array}{l}\text { Ministry of Social } \\
\text { Solidarity per Thousands } \\
\text { project }\end{array}$} & $\begin{array}{l}\mathrm{Y}=-23.04+0.839 \mathrm{X} \\
(.066-) \quad * *(4.62)\end{array}$ & 1403.27 & $67 \%$ & $21.33^{* *}$ \\
$\mathbf{2}$ & $\begin{array}{l}\text { Small Enterprise } \\
\text { Development Authority } \\
\text { per projects }\end{array}$ & $\begin{array}{c}\mathrm{Y}=7.29+0.896 \mathrm{X} \\
(0.08) *(4.39)\end{array}$ & 357.2 & $65 \%$ & $19.28^{*}$ \\
$\mathbf{3}$ & $\begin{array}{l}\text { Local Development } \\
\text { Fund per Projects }\end{array}$ & $\begin{array}{l}\mathrm{Y}=19.03-0.757 \mathrm{X} \\
* *(10.01)(3.47-)\end{array}$ & 13.2 & $53 \%$ & 12.09 \\
\hline
\end{tabular}

Source: Compiled and calculated from table data $(10),(*)$ Significant at 5\%, $\left({ }^{*}\right)$ Significant at 1\%

\section{Political empowerment of women:}

It is to enhance her leadership roles by stimulating the political participation of women in all its forms, including parliamentary representation at the national and local levels, preventing discrimination against women holding leadership positions in executive and judicial institutions, and preparing women to succeed in these positions. Also, it aims to raise the percentage of women in the judiciary and parliament, and establish a culture of equality between men and women, and bridge the gender gap between them, as well as provides them equal opportunities for ministries to activate them primary function in emphasizing the principle of constitutional equality in the field of work, and to address any discriminatory practices faced by both sexes (Mlak El-Tahawy, 2016)

Table (13) clarifies the percentage of females in holding high positions in jobs in state institutions, where the table data indicate the multiplicity of financial grades. 
Career and its graduation from (Excellent - High Class - General Manager - Senior - First Class - Second - Third - Fourth - Fifth - Fifth - Sixth - Equivalent - Contracts - Special Cadres) where the percentage of women participating in these positions reached $(18.8 \%-15.4 \%-18.2 \%-23.3 \%-14.4 \%$ $-14.5 \%-12 \%-7.2 \%-9.7 \%-10.3 \%-4.8 \%-11.5 \%-11.9 \%-12.4 \%)$ of the total workers respectively.

Table 13: Percentage of females in the top positions and distribution of civil servants in the public sector according to gender and functional degree in 2017

\begin{tabular}{cccccccc}
\hline $\begin{array}{c}\text { Financial class } \\
\text { /type }\end{array}$ & Excellent & High & $\begin{array}{c}\text { General } \\
\text { Manager }\end{array}$ & Senior & First & Second & Third \\
\hline $\begin{array}{c}\text { Males } \\
\text { Females }\end{array}$ & 286 & 1625 & 5274 & 18120 & 109962 & 93316 & 181641 \\
$\begin{array}{c}\text { Total } \\
\text { \% }\end{array}$ & 352 & 1921 & 6450 & 23616 & 128389 & 109125 & 206514 \\
$\begin{array}{c}\text { Female of the } \\
\text { total }\end{array}$ & 18.8 & 15.4 & 18.2 & 23.3 & 14.4 & 14.5 & 12 \\
\hline
\end{tabular}

Table 13: Continued

\begin{tabular}{|c|c|c|c|c|c|c|c|c|}
\hline $\begin{array}{c}\text { Financial } \\
\text { class } \\
\text { /type }\end{array}$ & Third & Fourth & Fifth & Sixth & $\begin{array}{c}\text { Comprehensive } \\
\text { Rewards }\end{array}$ & Contracts & $\begin{array}{l}\text { Special } \\
\text { Cadre }\end{array}$ & Total \\
\hline Males & 181641 & 66558 & 34126 & 14678 & 10915 & 51339 & 136838 & 724678 \\
\hline Females & 24873 & 5139 & 3660 & 1693 & 547 & 6657 & 18431 & 102270 \\
\hline $\begin{array}{c}\text { Total } \\
\%\end{array}$ & 206514 & 71697 & 37786 & 16371 & 11462 & 57996 & 155269 & 826948 \\
\hline $\begin{array}{c}\text { Female of } \\
\text { the total }\end{array}$ & 12 & 7.2 & 9.7 & 10.3 & 4.8 & 11.5 & 11.9 & 12.4 \\
\hline
\end{tabular}

\section{Economic Empowerment of Women:}

The concept of women's economic empowerment:

The term empowerment was emerged in the nineties of the twentieth century through women's international documents, It means removing all obstacles to women's access to their natural rights, and therefore women obtaining the right to achieve their ambition and participate in making decisions, whether economic or political, equally with the other half of society (men), These advantages were women deprived of it, or restricted in their use due to circumstances Surrounding and some misconceptions, customs and traditions.

Therefore,, women's economic empowerment means their full empowerment of the means and tools of production to manage and benefit from them, therefore, they take their opportunity to achieve economic gains and freedom in making economic decisions, and their extraction from low-wage work for others or seasonal work, also the goal of women's economic empowerment is active participation and requires development Women themselves and develop their capabilities and capabilities to possess the elements of a strength that enables them to bring about change in their society, and the availability of strengths such as self-confidence and work and before them education. In a brief statement, it can be said that women's economic empowerment means enhancing their economic participation in the workforce in both production and consumption.( International Bank for Reconstruction and Development 2018)

The economic empowerment of Egyptian women also aims to address the factors that affect the economic empowerment of Egyptian women radically, and develop the capabilities of women to expand work options in front of them, and increase their participation in the workforce, and achieve equal opportunities in employing women in all sectors, including the private sector and entrepreneurship. These are indicators on which to measure the extent of the success of the economic empowerment process, so that the economic opportunities available to women are not less than their ability, and in this context, a report by "Us \& Company" on women and the work in Egypt in 2012, estimated that if female employment rates become equal to employment rates Male in Egypt, this will increase the proportion of women contributing 34\% of the Egyptian GDP. (International Bank 2018)

The results of the research on the current state of women's economic empowerment indicate that the percentage of small projects directed to women is about $22.5 \%$, the percentage of micro-lending directed to women is about $45 \%$, and the percentage of females who have a bank account are about $9 \%$, and the average female wage in various economic activities (Monthly) about 1084 pounds less than the 
minimum wage, the average number of working hours per week is about 49 hours. As shown in Table (14) the economic situation of women in 2017 and the target in year 2030.

Table 14: Women's Economic Situation in 2017 and Target 2030 .

\begin{tabular}{clcc}
\hline Series & The statement & $\mathbf{2 0 1 7}$ & $\mathbf{2 0 3 0}$ \\
\hline $\mathbf{1}$ & Proportion of women living below the poverty line & $26.30 \%$ & $9 \%$ \\
$\mathbf{2}$ & Women's participation rate in the labor force & $24 \%$ & $35 \%$ \\
$\mathbf{3}$ & Female unemployment rate & $24 \%$ & $16 \%$ \\
$\mathbf{4}$ & Proportion of women in managerial positions & $6.50 \%$ & $12 \%$ \\
$\mathbf{5}$ & Proportion of women in professional positions & $38.50 \%$ & $48 \%$ \\
$\mathbf{6}$ & Income ratio between females and males & $29 \%$ & $58 \%$ \\
$\mathbf{7}$ & Proportion of small projects targeted at women & $22.50 \%$ & $50 \%$ \\
$\mathbf{8}$ & Ratio of microcredit directed to women & $45 \%$ & $53 \%$ \\
$\mathbf{9}$ & Percentage of females who have a bank account & $9 \%$ & $18 \%$ \\
$\mathbf{1 0}$ & Average female wage in different economic activities (monthly) & 1084 pounds & 5000 pounds \\
$\mathbf{1 1}$ & Average number of working hours per week & 49 hours & 100 hours \\
\hline
\end{tabular}

Source: - Central Agency for Public Mobilization and Statistics, 2030 Development Strategy.

\section{Impact measurement indicators of economic empowerment:}

Through a number of interventions for the economic empowerment of Egyptian women, such as:

1- Developing economic investment policies, management and financing systems, and developing policies to ensure the private sector is adequately represented by women on corporate boards.

2- Activating policies and procedures that encourage women to set up their own businesses; expanding business development services directed at women, applying single-window systems for women who are invested, and expanding the application of experiences in establishing cooperatives of economic activity directed for women.

3 - Providing financial services for savings promotion initiatives, group lending for women; developing banking and non-banking financial services for women, increasing women's knowledge of them and facilitating their access to them, especially through soft electronic channels, including direct loans to the Small and Medium Enterprises for Women.

4- The need to put laws and procedures that help preserve the rights of women working in the informal sector; and conduct studies on the economic contribution of unpaid women's work within the home, as a basis for spreading a culture that values women's work.

\section{Social Empowerment of Women:}

It is creating opportunities for greater social participation of women, and expanding their capabilities to choose and prevent practices that perpetuate discrimination against, or harmful to women, whether in the public field or within the family, legal support, family planning, reproductive health and specific support for some special groups.

\section{Impact measurement indicators of social empowerment:}

Through a number of interventions for the social empowerment of women, such as:

1- Establishing a network of counseling and legal services offices to support women, especially the poor, in reaching justice through awareness of their rights and helping them obtain them by law, activating the role of complaints offices of the National Council for Women to become the first asylum channel for women to solve their problems.

2- Developing social incentive systems to encourage women to organize reproduction with birth spacing in order to preserve the mother and child; to serve the elderly woman, awareness programs should be expanded on how family members interact with elderly women to improve the quality of their lives; and to develop health services for the elderly that take into account the needs of the elderly woman.

3- Enhancing the services of female prisoners by providing the necessary health care for female prisoners, especially the elderly, to facilitate the procedures for female prisoners to see their children, especially those with children under 15 years of age.

4- Educational campaigns to change society's perception of women prisoners and encourage them to accept them and reintegrate them into society once they have performed the punishment.

5- Confronting the problem of fine women's to raise their awareness of their rights and legal responsibilities to avoid the consequences of project faltering due to not thoughtful borrowing. 
Table (15) shows the social and health status of women in 2017 and the target in year 2030.

Table15: The social and health status of women in 2017 and the target of 2030

\begin{tabular}{|c|c|c|c|}
\hline Series & The statement & 2017 & 2030 \\
\hline 1 & Illiteracy rate among females aged 10 years & $27 \%$ & $12 \%$ \\
\hline 2 & (Illiteracy rate among females aged( 20-29 year & $12 \%$ & $0 \%$ \\
\hline 3 & Percentage of female university graduates & $56.20 \%$ & $78 \%$ \\
\hline 4 & Percentage of married women using family planning methods & $59 \%$ & $72 \%$ \\
\hline 5 & Caesarean births & $52 \%$ & $34 \%$ \\
\hline 6 & Number of nursing homes & 171 & 1400 \\
\hline 7 & Proportion of females employed in the government sector & $1 \%$ & $3 \%$ \\
\hline 8 & Percentage of female presence in judicial bodies & $0.50 \%$ & $25 \%$ \\
\hline 9 & Percentage of females who experienced sexual violence before marriage (rape) & $5 \%$ & $0 \%$ \\
\hline
\end{tabular}

Source: - Central Agency for Public Mobilization and Statistics,2030 Development Strategy.

\section{Protection Empowerment of women:}

It means protecting her from any harm, whether physical or psychological, such as sexual harassment, violence and bullying against women.

Sexual harassment and violence are among the phenomena that have developed in the Egyptian society in recent years, and data indicate that 2.5 million women have been subjected to harassment in 2017, and the economic cost of facing violence against women and harassment in public places annually to 571 million pounds. The data indicate that $6.6 \%$ of women were harassed in public transport, $9.6 \%$ were exposed to it on the street, $1.3 \%$ were exposed to it in educational institutions, and $3.7 \%$ experienced it in the workplace. Therefore, to reduce this phenomenon, it is necessary to increase the punishment for harassment, and the protection of women. Although the law prohibits early marriage in Egypt (marriage before the age of $18 \%$ ), where $17 \%$ of girls marry before 18 years, early marriage has negative consequences for a woman's health and academic achievement, and is directly related to the low rate of participation in the labor force,

This phenomenon is more prevalent in the countryside, especially in Upper Egypt, where poverty rates rise and about $56.8 \%$ of the rural population are unable to meet their basic needs. These social disadvantages and gender inequality led to a slowdown in economic activity, and this resulted in bad effects on women, as poverty rates increased among women to $27 \%$ in 2015 , compared to $26 \%$ in 2013 , compared to men. As a result, families' ability to access food has been negatively affected. and high rates of stunting and anemia.

Table 16: Shows the indicators of impact measurement to enable protection in 2017 and the target in 2030.

\begin{tabular}{|c|c|c|c|}
\hline Series & Statement & 2017 & 2030 \\
\hline 1 & Illiteracy rate among females aged 10 years & $27 \%$ & $12 \%$ \\
\hline 2 & (Illiteracy rate among females aged( $20-29$ year & $12 \%$ & $0 \%$ \\
\hline 3 & Percentage of female university graduates & $56.20 \%$ & $78 \%$ \\
\hline 4 & $\begin{array}{l}\text { Percentage of married women using family } \\
\text { planning methods }\end{array}$ & $59 \%$ & $72 \%$ \\
\hline 5 & Caesarean births & $52 \%$ & $34 \%$ \\
\hline 6 & Number of nursing homes & 171 & 1400 \\
\hline 7 & $\begin{array}{l}\text { Proportion of females employed in the government } \\
\text { sector }\end{array}$ & $1 \%$ & $3 \%$ \\
\hline 8 & Percentage of female presence in judicial bodies & $0.50 \%$ & $25 \%$ \\
\hline 9 & $\begin{array}{l}\text { Percentage of females who experienced sexual } \\
\text { violence before marriage (rape) }\end{array}$ & $4.10 \%$ & $0 \%$ \\
\hline
\end{tabular}

Source: - Central Agency for Public Mobilization and Statistics 2030 Development Strategy.

\section{Recommendations:}

1- Facilitating the administrative and technical procedures for projects directed to women to borrow from the Small Enterprise Development Agency and the Local Development Fund, which leads to increasing the economic empowerment of rural women. 
2- Raising the efficiency of financing for micro-projects for rural women and thus activating their role in rural development, and raising the level of efficiency of workers in the field of women's lending

for micro-projects, through serious training courses with an adequate evaluation to evaluate them.

3-Provide protection for women from any harm.

4- Increasing the rate of economic, social and political empowerment of women.

\section{References}

Central Agency for Public Mobilization and Statistics - Annual Bulletin of Manpower Research -2018.

Iman Akour, 2016. Economic Empowerment of Women, Reality and Prospects, Jordanian Ministry of Labor as a model - Economic Empowerment Section, Ministry of Labor,

International Bank for Reconstruction and Development (IBRD / World Bank): A Study on Women's Economic Empowerment, 2018 - Website: www.worldbank.org

Local Development Fund - Information and Decision Support Center, unpublished data.

Mlak Mohamed El-Tahawy, 2016. Women and Social Mobility in the Informal Sector: Field Study, Socio-Economic Analysis, Department of Sociology, Faculty of Arts, Minia University.

Ministry of Social Solidarity - Follow-up Center - unpublished data.

Mona Abdel-Aal Desouky, 2015. Financing for Women Development, Arab Women Conference on Development Agenda 2015-2030, Egypt, 29 November-1 December.

Said, A., M.S. Refaat, 2002.The Role of the Social Fund for Development in the dissemination of small projects in the Egyptian countryside, National Innovation and Technology Conference for Building Competitiveness of Small and Medium Enterprises, Mansoura University, March.

Salwa Amer Khader, 2018. The role of microfinance in the economic empowerment of rural women, the Egyptian Journal of Agricultural Economics 28 (2) 859.

Small Enterprise Development Authority - Information and Decision Support Center, unpublished data. 